9. Tarasov, V.I. (2016). Rozvytok yaruzhnoyi erozii v Stepu Pivnichnomu Ukrainy [Development of gully erosion in the Northern Steppe of Ukraine]. Visnyk ahrarnoi nauky - Bulletin of agrarian science, 5 , 60-63 [in Ukrainian].

10. Bulyhin, S.Yu. \& Achasov, A.B. (2012). Vykorystannia heoinformatsiinykh tekhnolohii dlia gruntovoho kartohrafuvannia [The use of geo-information technologies for soil mapping]. Visnyk ahrarnoi nauky - Bulletin of agrarian science, 10, 52-56 [in Ukrainian].

11. Nazarok, P.H., Kruhlov, O.V., Kutsenko, M.V., Menshov, O.I., Sukhorukova, A.V. (2015). Do problemy kartohrafuvannia eroziynykh protsesiv [To the problem of mapping erosion processes]. Visnyk ahrarnoi nauky - Bulletin of agrarian science, 9, 63-68 [in Ukrainian].

12. Kulik, K.N., Zubov, A.R., Zykov, I.G. \& Zubov, A.A. (2018). Metodologiya izucheniya erozionnykh protsessov v lesoahrarnykh i tekhnogennykh landshaftakh: monohrafiya [Methodology of studying erosion processes in forest and technogenic landscapes: monograph]. Volgograd: FNTs agroekologiy RAN [in Russian].
13. Zubova, L.G. (2013). Osnovy matematicheskoy obrabotki eksperimentalnykh dannykh: uchebnoye posobiye [Fundamentals of mathematical processing of experimental data: tutorial]. Lugansk: Noulidzh [in Russian].

14. Kruzhskiy, N.K. \& Polupan, N.I. (Eds.). (1979). Atlas pocho Ukrainskoy SSR [Atlas of Soils of the Ukrainian SSR]. Kyiv: Urozhay [in Russian].

15. Vernader, N.B., Gogolev, I.N., Kovalishin, D.I. (1986). Priroda Ukrainskoy SSR. Pochoy [Nature of the Ukrainian SSR. Soils]. Kyiv: Naukova dumka [in Ukrainian].

16. Belolipskiy, V.A., Shelyakin, N.M. \& Igumentsev, A.F. (1985). O metodakh izucheniya erozionnykh protsessov [On the methods of studying erosion processes]. Pochvovedeniye - Soil Science, 12, 98-105 [in Russian].

17. Befani, N.F. \& Kalinin G.P. (1965). Uprazhneniya $i$ metodicheskiye razrabotki po gidrologicheskim prohnozam: uchebnoye posobiye [Exercises and methodological development of hydrological forecasts: a tutorial]. Leningrad: Gidrometeoizdat [in Russian].

Стаття надійшла до редакції журналу 12.04.2019

\title{
PROBLEMS OF SOIL BONING IN ZAPORIZHZHIA REGION IN MODERN LAND RESOURCES ASSESSMENT
}

\section{Datcenko ${ }^{1}$, S. Hryshko ${ }^{2}$, M. Ganchuk ${ }^{1}$, N. Tarusova ${ }^{1}$, Y. Chebanova ${ }^{1}$, V. Scherbina ${ }^{1}$, V. Skyba ${ }^{1}$, A. Anhelovska ${ }^{1}$}

\footnotetext{
${ }^{1}$ Таврійський державний агротехнологічний університет імені Дмитра Моторного

${ }^{2}$ Мелітопольський держсавний педагогічний університет імені Богдана Хмельницького
}

\begin{abstract}
Наведено короткий огляд робіт щодо бонітувального стану грунтів у незалежній Україні. Охарактеризовано методики Л.Я. Новаковського, А.І. Сірого, В.В. Медведєва та I.В. Пліско. Апробовано чинну методику бонітування грунтів, що була запропонована фахівиями науково-дослідних установ НААН та Національного аграрного університету, в умовах Запорізької обл. На основі власних польових досліджень, даних лабораторії моніторингу грунтів і якості продукції рослинництва Таврійського держсавного агротехнологічного університету імені Дмитра Моторного, матеріалів Запорізької філії ДУ «Інститут охорони грунтів України», а також аналізу грунтових карт, картограм агровиробничих груп грунтів, даних фізико-хімічних властивостей і морфологічних ознак грунтів представлено якісну оцінку грунтів області за районами та здійснено класифікацію їх угрупувань за вмістом гумусу, що дало можливість скласти відповідні карти.
\end{abstract}

Ключові слова: бонітування грунтів, методика бонітування грунтів, родючість грунту, гумус, Запорізька обл.

The most alarming situation in the agricultural sphere of the state nowadays is a

(C) L. Datcenko, S. Hryshko, M. Ganchuk, N. Tarusova,

Y. Chebanova, V. Scherbina, V. Skyba, A. Anhelovska, 2019 steady decline of soil fertility. The state of land resources and soil quality of Ukraine worsen. The areas of technogenic pollution are growing, and the soils of Zaporizhzhia Re- 
gion are no exception. Under such conditions, particular relevance related to the determination of the qualitative composition of the land. The integrated natural characteristics of the soils are reflected by such an index as scales of soil evaluation.

According to the criterion of productive activities the main purpose of agricultural land is the production of crops with appropriate yields of agricultural crops. Generally, yield indicators depend on both the natural properties of soils and the natural and climatic conditions of land location and on the technologies of cultivation of the crops. There is a connection between land as an economic category, soil fertility, crop yields and assessment of land [1]. Evaluation of land resources remains to be the most relevant field of research in the assessment of natural resources. It should be mentioned that the lack of consensus among experts about the assessment of land as an element of national wealth requires the revision of traditional methods of assessment of land resources.

\section{MATERIAL AND METHODS}

Field trials. The methods of field trial were fundamental and were used to study the soil varieties of the region under research. The profile method allowed exploring the soil from the surface to the depth of its thickness by genetic horizons to the maternal rock, which gave an opportunity to codify the basic types of soils. The morphological method is an effective way for examination of soil's properties by external features: color, structure, content, neoformations and inclusions, the depth and sequence of bedding of rocks, etc. The method was principal for conducting field soil trials and was the basis of field soil diagnostics. By using this method three types of morphological analysis were carried out: macro- - with the naked eye; mezo- - with the use of a magnifying glass and binoculars, micro- - with a microscope.

Laboratory and Experimental Research. Laboratory tests involved determining the content of humus in the selected soil samples on the territory of Melitopol District
(26 samples). Analysis of the samples was carried out on the basis of the laboratory of «Monitoring of Soils and Quality of Crop Production» TSATU by I.V. Turin's method of humus determination. This method is based on the oxidation of humus carbon to $\mathrm{CO}_{2}$ with the solution of potassium bichromate in sulfuric acid, the excess of which is titrated with Mora salt. The research results showed that the content of humus on the territory of Melitopol District varies from 2 to 3\% depending on the type of soil. Such an indicator of the content of humus is quite low, even compared with the contents of humus indicators in other soil types in Zaporizhzhia Region. The tendency can be explained by both natural (erosion, deflation, the prevalence of chestnut and dark chestnut soils in the region of various degrees of salinization, possessing naturally low indicators of the content of humus substances) and anthropogenic factors (erosion, insufficient injection of organic fertilizers, depletion of humus substances as a result of irrational land utilization).

Data and Statistical Analysis. In the research the statistical data of GE «Zaporizhzhia Regional State Project-technological Center of Guard of Soil Fertility and Quality of Products», on the content of humus in different types of soils in the Zaporizhzhia Region were used. Moreover, the available cartographic material on soils of the region was analyzed. The use of geoinformation and cartographic modeling allowed creating the map of soil fertility levels and the content of humus in them for administrative districts of Zaporizhzhia Region with the use of ArcGIS geoinformation program.

\section{RESULTS AND DISCUSSION}

Soil evaluation is a comparative assessment of quality of soils according to their main natural properties that have a permanent character and substantially affect the yields of agricultural crops grown in specific climatic conditions. Soil evaluation is carried out on a 100-point scale. At the top of the scale is soil with the best properties which possesses the greatest natural productivity [1]. Soil evaluation is an integral part of the 
state land cadaster, which ensures highly efficient use of land resources aimed at improving the soil fertility and crop yields. Being a logical completion of soil examination and a generalizing state in the study of soils, the data of soil evaluation are used in agriculture, land management and land evaluation.

Legal significance of soil evaluation resides in the fact that the information about the quality status of soils of a certain climatic zone is the source for the economic and monetary evaluation of plots of land for the calculation of compensation of diseconomies of agricultural and forestry production, as well as losses caused by the withdrawal of land plots for public purposes. Moreover, soil evaluation is the basis for the development of a set of measures related to the protection of agricultural land [2].

In the 90 -ies of the twentieth century after Ukraine gained the independence before the economic evaluation of lands was conducted, the necessity for information about the comparative assessment of soil quality arose. Therefore, in 1993, a continuous soil quality evaluation of agricultural land of Ukraine was first held on the basis of «Methods of soil quality evaluation in Ukraine», which were developed in 1992 by experts of the research institutions of Ukrainian Academy of Agrarian Sciences (Institute of Land Utilization, Institute of Soil Science and Agrochemistry named after O.N. Sokolovskiy, Institute of horticulture) and National Agrarian University (hereinafter method 1) [3]. This method of soil evaluation is recognized at state level and has been used by us during research, but in parallel there are other methods of soil evaluation, in particular methods of A.I. Siryi (hereafter method 2) [4], V.V. Medvedev and I.V. Plisko (hereafter method 3) [5].

The essence of method 1 is that objects of soil evaluation are units of soil, which are highlighted on soil maps and united into soil agricultural enterprises according to the «Nomenclature List of Agro-industrial Soils of Ukraine» within the boundaries of natural and agricultural areas. In the process of highlighting the homogeneity of properties of soils and climatic conditions, peculiari- ties of agricultural production, as well as the administrative-territorial division of Ukraine are taken into account [3]. According to method 2, the primary unit of soil evaluation is an elemental soil area, and according to method 3, the spatial unit of soil evaluation should be a type of soil.

The work on soil evaluation consists of several stages and is carried out in the following order:

1) clarification of natural-agricultural zoning of the land fund;

2) making a list of the agro-industrial groups of soils;

3) agroeconomic substantiation of placement of agricultural crops;

4) processing and collecting data about soil properties;

5) choice of reference soils for evaluation;

6) development of scales of soil evaluation;

7) calculation of the points of soil evaluation.

Areas of crops cultivation have been highlighted, within which separate soil evaluation of the main agricultural crops has been held. A.P. Kanash [6] notes that it can be considered as a specialized classification of natural properties of soils, characterizing their fertility in relation to different crops, and reflects the degree of correspondence of soil to the biological needs of specific crops.

According to method 2, the score of soil evaluation is established on the basis of objective natural properties and characteristics of soils, which act as criteria of soil evaluation. They are also divided into basic and modifying. However, the main criteria include those parameters, which directly characterize the ability of soils to meet the needs of plants in the factors of life (water and nutrients). Such parameters are the maximum possible reserves of productive moisture (range of active moisture), the reserves of humus, the content of active forms of nutrients (active phosphate and exchangeable potassium) [4, 7-9].

According to the developers of the method (3), 100 points should be given to the soil 
with parameters that would meet the physiological requirements of the crops and would help the maximum realization of their potential of productiveness. The determination of soil evaluation points is carried out in the most permanent and objective natural properties of soils that correlate with crop capacity. These properties, which serve as the criteria for appraisal, are divided into two groups: basic and modifying. The main criteria include the depth of humus horizon, the content of humus and physical clay in the arable layer (or the index of agrophysical state of soils). Modifying criteria (or correction factors) are those figures that are inherent to certain groups of the soils, namely salinity, gritty consistency, acidity, solonetzicity, gleization, erosion [5, 10-13].

Comparing the methods, it can be emphasized that in method 1 the score of soil evaluation is determined by the indicators of soils correlating with crop capacity, while in method 2 - by indicators that characterize the ability of soils to fit to the needs of plants in the factors of life. Also, differences in determination of the modifying characters can be noted. If in the method 1 these are indicators, inherent to certain groups of soils, in the method 2 modifying criteria are determined by specific soil properties, which cause a particular need of plants to use nutrients and moisture [14].

According to the method of soil quality evaluation by V.V. Medvedev, I.V. Plisko (3) «soil evaluation is an assessment of the productive capacity of the soil» [5]. According to method 3, it is necessary to conduct soil evaluation on the basis of indicators that characterize the potential and effective soil fertility: the granulometric composition and humus content of the soil, its structure and the ratio of pores of various sizes; the depth and density of the root layer (the volume of soil available for the roots); $\mathrm{pH}$ and indicators that characterize water-thermal and nutrient regimes during the critical periods of plant development. The authors call these figures «the criterion basis of soil evaluation». Consequently, the figures to identify scores of soil evaluation according to method 3 fully reflect the properties of the tested soil. But a question arises, how much time it is necessary in order to analyze the soils on the whole territory of Ukraine. At the same time, this poses a question of funding for such research.

Having analyzed various methods of soil evaluation, it should be noted that each of these methods deserves attention because they are aimed at a comprehensive study of the qualitative assessment of soils. But according to the «soil evaluation» definition of article 99 of the Land Code of Ukraine [1], in our opinion, currently method 1 is the most acceptable, even though it needs some improvement.

On the basis of this method [3] a study of soils in Zaporizhzhia Region was conducted, using the soils map, cartograms of agro-industrial soil groups, data about the physical and chemical properties and morphological features of the soils. The object of soil evaluation was small taxonomic units, such as types and soil varieties. The assessment of the level of fertility of lands of Zaporizhzhia Region has been carried out by district, considering that the yield of crops due to soil differences is not conducted. The criterion for evaluation was the average long-term yield of grain crops in points (excluding expenditures). The value of one point is $0.41 \mathrm{~h} / \mathrm{ha}$. Taking into account the results of the research, a qualitative assessment of the soils of the region by administrative districts in points is presented (Fig. 1).

Group I. Soils fertility is over 72 points: ordinary low-humus chernozems on loess rocks, southern low-humus chernozems on loess rocks, meadow and chernozem-meadow solonetz-like soils on loess rocks and modern alluvium, meadow-chernozem gleyed solonetz-like soloded of the bottom, sod-sand and clay-sand soils. The productivity of the objects of area of economic significance increases during irrigation, and meadow-chernozem soil requires for continuous gypsuming with simultaneously deep ploughing $(27-30 \mathrm{~cm})$ without pulling out gleyic infertile horizon on the surface. This soil fertility is represented in Mikhailivka District.

Group II. Soils with assessment in 6872 points: ordinary low-humus chernozems 


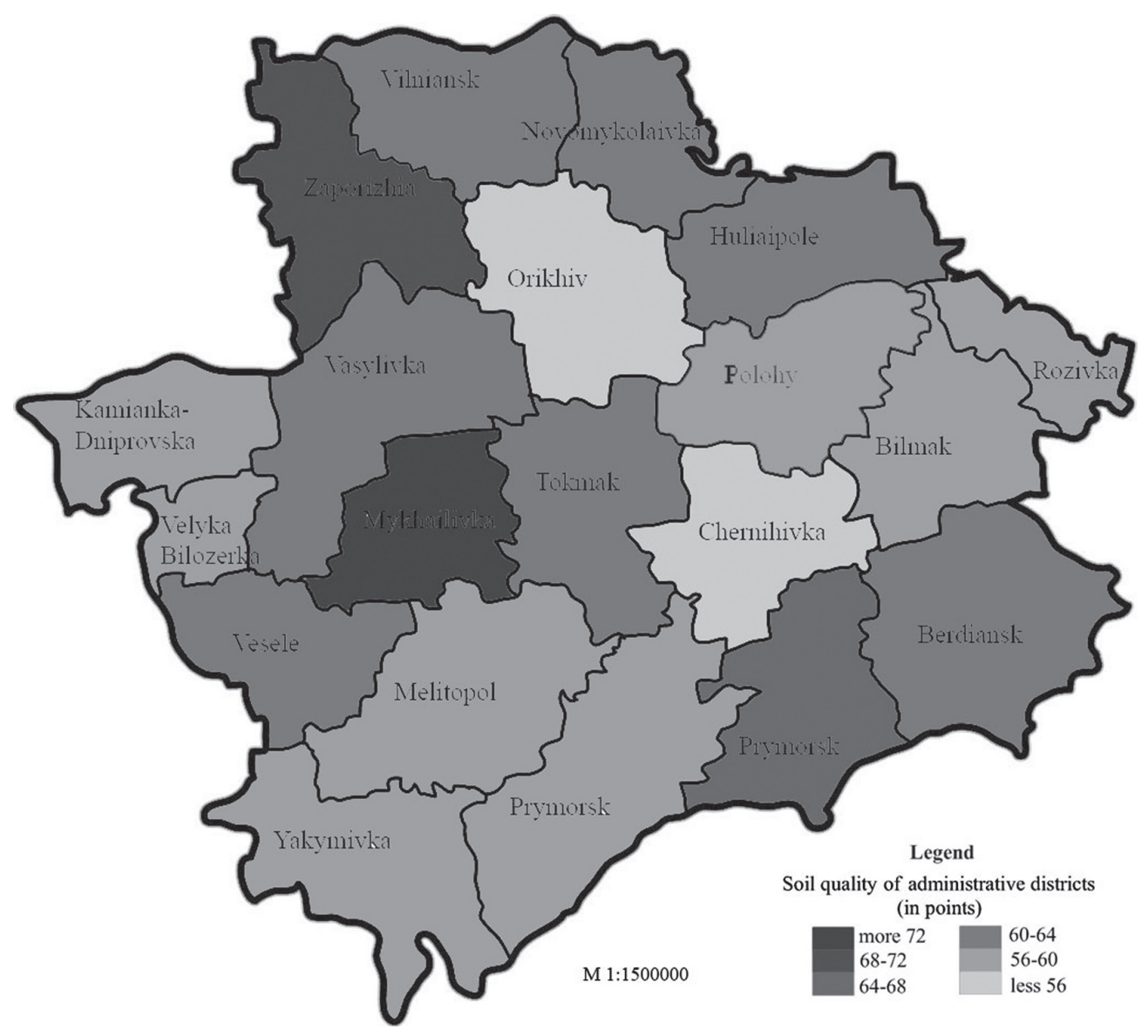

Fig. 1. Level of Soil Fertility in Zaporizhzhia Region

on loess rocks, meadow-chernozem on deluvium and alluvium deposits, sod-sand and clay-sand soils. Besides irrigation on these soils, the fixed applying fertilizers are urgent. The soils with this point of fertility are represented in Zaporizhzhia Region.

Group III. Soils fertility with assessment in 64-68 points: ordinary low-humus chernozems on loess rocks southern low-humus chernozems on loess rocks, chernozems mainly break-stoned on eluvium of solid non-carbonate rocks, dark chestnut residual solonetz-like on loess rocks, meadow and chernozem-meadow solonetz-like on loess rocks and modern alluvium, sod-sand and clay-sand soils of spits and earthen banks of the Sea of Azov and lagoons, alcali soils; alcali soils in complex, salty soils and saline ooze; salty soils in complex. It is useful to combine irrigation with using small doses of gypsum for preventing further salination as well as with the fixed applying of fertilizers. The soils with this point of fertility are located in Prymorsk District.

Group IV. Soils with assessment in 6064 points: ordinary low-humus chernozems on loess rocks, southern low-humus chernozems on loess rocks, residual solonetzlike chernozems on solid clays, chernozems mainly break-stoned on the eluvium of solid non-carbonate rocks, ordinary residual solonetz-like chernozems on loess rocks, meadow chernozems solonetz-like soils on alluvium deposits chestnut residual solonetz-like soils on loess rocks, meadow and chernozem- 
meadow solonetz-like soils on loess rocks and modern alluvium, chernozem-meadow gleyed solonetz-like soloded soils of the bottoms, sod-sand and clay-sand soils of spits and earthen banks of the Sea of Azov and lagoons. Irrigation, gypsuming, and applying of fertilizers are needed. The soils with this point of fertility are studied in Vilniansk, Novomykolaivka, Huliaipole, Tokmak, Vasilivka, Vesele and Berdyansk Districts.

Group V. Soils with fertility in 5660 points: ordinary low-humus chernozems on loess rocks, southern low-humus chernozems on loess rocks, residual solonetz-like chernozems on solid clays, chernozems mainly break-stoned on the eluvium of solid noncarbonate rocks, chernozem and sod claysand and loamy sand soils on sandy alluvium, ordinary residual solonetz-like chernozems on loess rocks, meadow chernozem soil on deluvium and alluvium deposits, dark chestnut residual solonetz-like soils on loess rocks, chestnut solonetz-like soils on loess rocks, meadow chestnut solonetz-like soils on loess rocks, meadow and chernozem-meadow solonetz-like soil on loess rock and modern alluvium, meadow chernozem gleyed solonetz-like soloded soils of the bottoms, sod-sand and clay-sand soils of spits and earthen banks of the Sea of Azov and lagoons, alcali soils; alcali soils in complex, salty soils and saline ooze; salty soils in complex. Desides irrigation and applying fertilizers, gypsuming and specific meliorative measures are also needful. The soils with this point of assessment are located in Polohy, Bilmak, Rozivka, Kam'yanskaDniprovska, Velyka Bilozerka, Melitopol, Yakymivka and Pryazovske Districts.

Group VI. Soils with fertility about 56 points: low-humus chernozems on loess rocks, southern low-humus chernozems on loess rocks, residual solonetz-like chernozems on solid clays, black earth mainly break stoned on the eluvium of solid non-carbonate rocks, chernozem and sod clay-sand and loamy sand soils on sandy alluvium, common fesidual solonetz-like chernozem on loess rocks. For increasing fertility on these soils irrigation applying fertilizers, gypsuming (on solonetz- like soils) as well as special methods of cultivation practice (deep ploughing without the turn of the layer, harrowing etc.) can be recommended. The soils with such fertility are presented in Orikhiv and Chernihivka Districts.

The main indicator of soil fertility is the content of humus. According to GE «Zaporizhzhia Regional State Project-technological Center of Guard of Soil Fertility and Quality of Products» as of 01.01.2017, and the research of «Monitoring of Soil and Quality of Crop Production» TSATU, a map of humus content by the administrative districts of Zaporizhzhia Region has been compiled (Fig. 2). The highest content of humus is found in ordinary chernozem in Rozivka, Bilmak, Novomykolaiv and Huliaipole Districts $-3.93-4.41 \%$. At least $2.40-2.99 \%$ of humus was found in dark chestnut soils in the Yakymivka, Priazovske, Melitopol Districts and ordinary chernozem with medium and loamy deposits in the Kam'yanska-Dniprovska, Vasilivka and Zaporizhzhia Districts. Especially large decrease of humus (by $0.11-$ $0.15 \%$ ) was detected in the Prymorsk, Berdyansk and Vilniansk Districts.

Humus is an important source of nutrients, but the dynamics of this indicator is unsatisfactory. In general, according to GE «Zaporizhzhia Regional State Project-technological Center of Guard of Soil Fertility and Quality of Products», the content of humus in the region decreased by $0.1 \%$. In most districts there is a tendency to decrease in humus content. The main reason for the decrease of humus is extremely low application of organic fertilizers $(0.5 \mathrm{t} / \mathrm{ha})$ in recent years, insufficient supply of organic substances from nutrients and rest of roots, increased mineralization of organic substances as a result of intensive cultivation of tilled crops, wash-off of fertile humus layer of soil as a result of water erosion. The average content of humus in the region related to the reference $(6.2 \%)$ accounts for only $3.35 \%$. Consequently, all the soils in the region need preservation and increase of the amount of humus.

Thus, the specificity of the land resources of Zaporizhzhia Region is shown in the diver- 


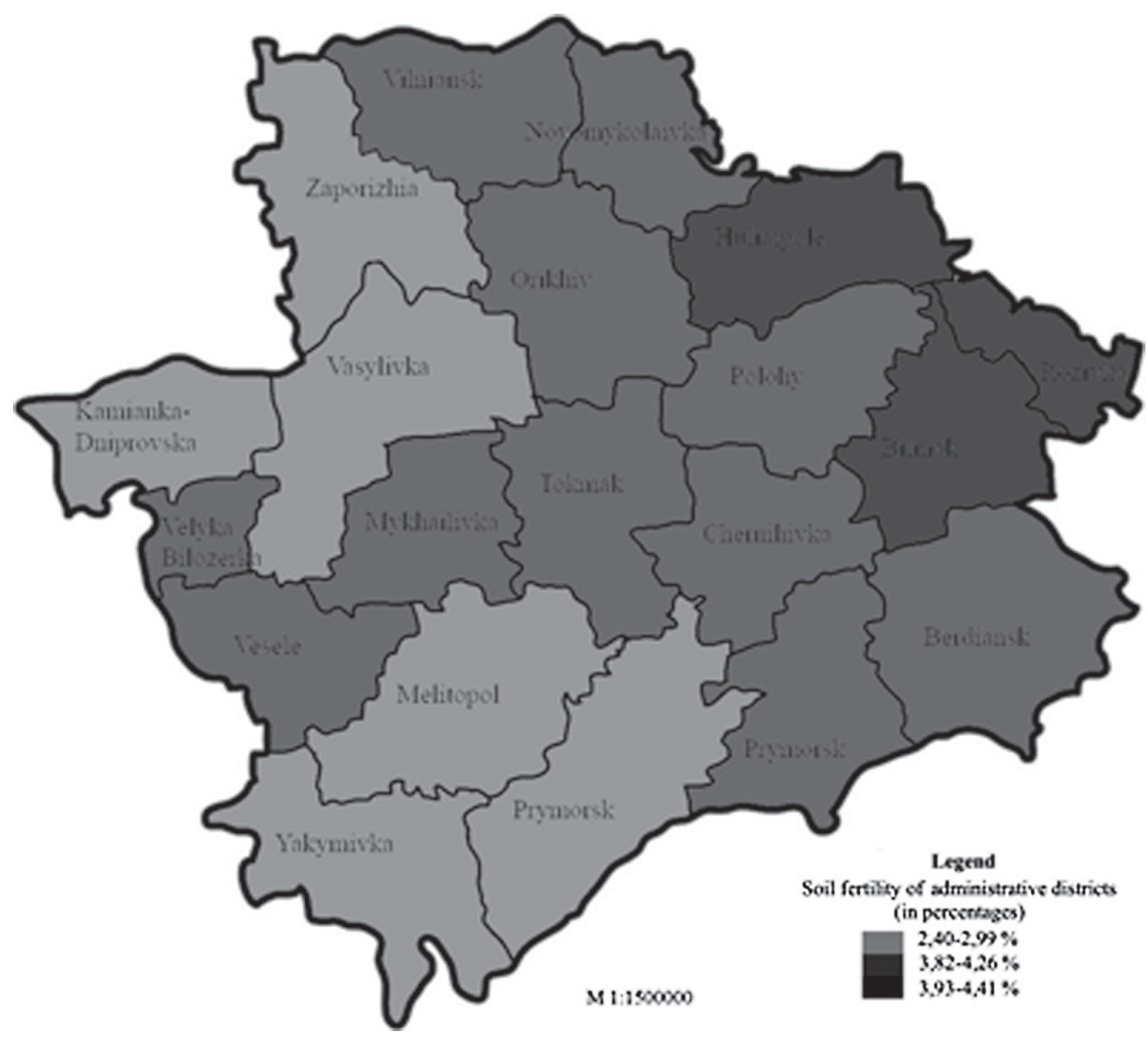

Fig. 2. Zoning of the Zaporizhzhia Region According to the Content of Humus

sity of soils, different levels of their fertility, high degree of development, the need to use reclamation measures that contribute to the natural and anthropogenic evolution of soil. At the same time, the productivity of various crops, even under the same edaphic conditions, is inadequate, since it depends on the characteristics of the cultivated plants, their needs from the environment.

\section{CONCLUSION}

Analysis of the most common methods of soil evaluation of Ukraine proves that the basic principle of soil evaluation is a comprehensive research of soil fertility, though the criteria of soil quality evaluation in various methods are distinctly different. In our opinion, modern soil evaluation should consider integral indicators, the major ones being: properties of soil, crop yields, natural-climatic conditions, technological conditions of cultivation of agricultural crops. According to the «Assessment of Lands» [15] Act of soils evaluation should be held once in 7 years, but the first round was held in 1993 with the application of an imperfect method. The second round has not been conducted so far. Such a situation in the system of evaluation of land resources indicates that the state does not observe the laws, ordinances and regulations regarding the most important measures related to the protection and rational use of soil. 
The research gives grounds to assume that the fertility of soils in Zaporizhzhia Region is decreasing from Northeast to Southwest and can be explained by physical and chemical properties and morphological signs of soils, as well as by yields of major agricultural crops. Every year the level of soil fertility of Zaporizhzhia Region has a tendency to decrease. The improvement of soil fertility should be carried out as a complex of measures of biological and economic influence, aimed at ensuring the optimum ratio between the moisture, aeration and necessary nutrients for plant.

Suggestions for improving soil fertility:

- to revise the existing and create new, more effective laws on the protection of soils and their fertility;

- to conduct the second round of soil evaluation with the use of an updated method, which will take into account the advanced world experience [16];

- to align the state of scientific maintenance of the problem of rational land utilization with the requirements of the time, especially the problems of overcoming the soil degradation, specifically: to engage geoinformation, remote, automated computer and other modern technologies - to provide reasonable spatial solutions, identification of degradation phenomena, erosion in particular, anti-degradation organization of agricultural territory, new methods of information organization in the form of databases and expert automated systems with expanded capabilities of reference volume;

- to reduce the gap between science, authorities and society, precisely soil scientists who develop recommendations for the protection of soils, managers who must create the conditions for their implementation, and agroindustry, which must actively accept scientific advice;

- to intensify international cooperation in order to develop an effective strategy to protect soils from degradation;

- to raise the ranking of the problems of protection of soil in the community.

\section{ЛІТЕРАТУРА}

1. Земельний Кодекс України від 25 жовтня 2001 р., № 2768-III, ст. 199 [Електронний ресурс] / Верховна Рада України. - Режим доступу: http: // zakon0.rada.gov.ua/laws/show/2768-14

2. Єрмоленко B.M. Правове забезпечення охорони та раціонального використання земельних ресурсів / В.М Єрмоленко, В.І. Курило, Т.С. Кичилюк. - К.: Магістр - XXI сторіччя, 2007. - 248 с.

3. Методические рекомендации по проведению бонитировки почв. - К.: УААН, 1993. - 96 с.

4. Бонитировка почв. Методические рекомендации / А.И. Серый, Н.А. Дубровина, В.А. Лапанова и др. - К.: УСХА, 1986. - 75 с.

5. Медведев В.В. Бонитировка и качественная оценка пахотных земель Украины / В.В. Медведев, И.В. Плиско. - Х.: Изд. «13 типография», 2006. $-386 \mathrm{c}$

6. Канаш О.П. Бонітування грунтів: пропонуються зміни, чого вони варті? / О.П. Канаш // Землевпорядний вісник. - 2008. - № 5. - С. 46-50.

7. Сірий А.І. Якісна оцінка грунтів / А.І. Сірий. К.: Знання, 1974. - 47 с.

8. Серый А.И. К методике бонитировки почв на агроэкологической основе / А.И. Серый // Почвоведение. - 1981. - № 7. - С. 5-17.

9. Серый А.И. Современные методы бонитировки почв в УССР. Обзорная информация / А.И. Серый, Н.А. Оголенко. - К.: УкрНИИНТИ, 1987. - 36 с.

10. До нової концепції бонітування грунтів / В.В. Медведєв, І.В. Пліско, К.Б. Сршова, Д.М. Бенцеровський // Вісник аграрної науки. - 2002. - № 9. - C. 13-18.
11. Медведєв В.В. Удосконалена концепція бонітування земель / В.В. Медведєв, І.В. Пліско // Вісник ХНАУ. - 2005. - № 1. - С. 39-43.

12. Медведєв В.В. Критерії, еталони і просторові одиниці в бонітуванні грунтів / В.В. Медведєв, I.В. Пліско // Вісник аграрної науки. - 2008. - № 8. - C. 9-15.

13. Медведєв В.В. Пропозиції до вдосконалення чинної методики бонітування грунтів / В.В. Медведєв, І.В. Пліско // Вісник аграрної науки. -2013. - № 5. - C. 14-18.

14. Тихенко O.B. Порівняльний аналіз методів бонітування грунтів України / О.В. Тихенко // Вісник Національного аграрного університету. - 2010. - № 6. - С. 33-39.

15. Закон України «Про оцінку земель» від 11.12.2003 р., № 1378-IV, ст. 16 [Електронний ресурс] / Верховна Рада України. - Режим доступу: http: // zakon2.rada.gov.ua/laws/show/1378-15

16. International Valuation Standards: GN 10 Valuation of Agricultural Properties, GN 13 Mass Appraisal for Property Taxation [Електронний ресурс ] / Australian Property Institute. - Australia and New Zealand: API, 2008. - 552 р. - Режим доступу: https://www.google.com.ua/url?sa=t\&rct=j\&q= $\& \operatorname{esrc}=s \&$ source $=$ web $\& c d=10 \& c a d=r j a \& u a c t=$ $8 \& \mathrm{v}$ e d $=2$ a h U K E w i $88 \mathrm{~s} \mathrm{v} \mathrm{K} \mathrm{y} \mathrm{c} \mathrm{-}$ D $1 \mathrm{~A} \mathrm{~h} \mathrm{X} \mathrm{O} \mathrm{o} 4 \mathrm{~s} \mathrm{~K} \mathrm{H} \mathrm{U} 9$ a C 48 Q F jAJegQIBxAC\&url=https $\% 3 \mathrm{~A} \% 2 \mathrm{~F} \% 2$ Fsrosovet. ru\%2Fcode\%2Fcore\%2Fdownload.php\%3F1804\& usg=AOvVaw1lUYOqs5Vv1ANoXiA0AjUD 


\section{REFERENCES}

1. Zemelnyi Kodeks Ukrainy vid 25 zhovtnia 2001 r., № 2768-III, st. 199 [Land Code of Ukraine of October 25, 2001, No. 2768-III, Art. 199]. (2001). Retrieved from http: // zakon.rada.gov.ua/laws/ show/2768-14 [in Ukrainian].

2. Yermolenko, V.M, Kurylo, V.I. \& Kychyliuk, T.S. (2007). Pravove zabezpechennja ohorony ta racional'nogo vykorystannja zemel'nyh resursiv. [Legal protection of land protection and national use]. Kyiv: Master - XXI Century [in Ukrainian].

3. Metodycheskye rekomendacyy po provedenyju bonytyrovky pochv [Methodical recommendations for soil evaluation]. (1993). Kiev: UAAS [in Russian].

4. Seryi, A.I., Dubrovina, N.A., Lapanova, V.A., Kozlov, N.V. \& Krikunov, V.G. (1986). Bonytyrovka pochv. Metodycheskye rekomendacyy [Soil evaluation. Methodical recommendations.] Kiev: UAA [in Russian].

5. Medvedev, V.V. \& Plisko, I.V. (2006). Bonitirovka $i$ kachestvennaja ocenka pahotnyh zemel' Ukrainy [Soil evaluation of and qualitative assessment of the arable lands of Ukraine]. Kharkov: Pub. «13 typography» [in Russian].

6. Kanash, O.P. (2008). Bonituvannja g'runtiv: proponujut'sja zminy, chogo vony varti? [Soil evaluation: what changes are they offered?]. Zemlevporiadnyi visnyk - Land management newosletter, 5, 46-50 [in Ukrainian].

7. Seryi, A.I. (1974). Jakisna ocinka g'runtiv [Qualitative assessment of soils]. Kyiv: Knowledge [in Ukrainian].

8. Seryi, A.I. (1981). K metodike bonitirovki pochv na agrojekologicheskoj osnove [To the method of soil evaluation on agroecological basis]. Pochvovedenie - Soil Science, 7, 5-17 [in Russian].

9. Seryi, A.I. \& Oholenko, N.A. (1987). Sovremennye metody bonitirovki pochv v USSR.[Modern methods of appraisal of soils in the USSR]. Kiev: UkrSRISTITER [in Russian].

10. Medvedev, V.V., Plisko, I.V., Yershova, K.B. \& Bentserovskyi, D.M. (2002). Do novoi' koncepcii' bonituvannja g'runtiv [To the new concept of soil evalu- ation]. Visnyk ahrarnoi nauky - Bulletin of Agrarian Science, 9, 13-18 [in Ukrainian].

11. Medvedev, V.V., Plisko, I.V. (2005). Udoskonalena koncepcija bonituvannja zemel' [Improved concept of land cultivation]. Visnyk KhNAU - KhNUU Bulletin. 1, 39-43 [in Ukrainian].

12. Medvedev, V.V. \& Plisko, I.V. (2008). Kryterii', etalony i prostorovi odynyci v bonituvanni g'runtiv [Criteria, benchmarks and spatial units in the soil evaluation]. Visnyk ahrarnoi nauky - Bulletin of Agrarian Science, 8, 9-15 [in Ukrainian].

13. Medvedev, V.V. \& Plisko, I.V. (2013). Propozycii' do vdoskonalennja chynnoi' metodyky bonituvannja g'runtiv [Proposals for the improvement of the current method of soil evaluation]. Visnyk ahrarnoi nauky - Bulletin of Agrarian Science, 5, 14-18 [in Ukrainian].

14. Tykhenko, O.V. (2010). Porivnjal'nyj analiz metodiv bonituvannja g'runtiv Ukrai'ny. [Analysis of the methods of productivity evaluation of soils]. Visnyk Natsionalnoho ahrarnoho universytetu - Bulletin of the National Agrarian University, 6, 33-39 [in Ukrainian].

15. Zakon Ukrai'ny «Pro ocinku zemel'» vid 11 gruden' 2003 r., № 1378-IV, st. 16 [The Law of Ukraine «On Land Assessment» dated December 11, 2003, no. 1378-IV, art. 16]. (2003). zakon2.rada.gov.ua. Retrieved from http: // zakon2.rada.gov.ua/laws/ show/1378-15 [in Ukrainian].

16. International Valuation Standards: GN 10 Valuation of Agricultural Properties, GN 13 Mass Appraisal for Property Taxation. (2008). Australian Property Institute Australia and New Zealand: Australian Property Institute. wrw.google.com.ua. Retrieved from https://www.google.com.ua/url?sa=t\&rct=j $\& \mathrm{q}=\&$ esrc $=$ s\&source $=$ web $\& \mathrm{~cd}=10 \& \mathrm{cad}=$ rja\&uact $=8 \&$ ved $=2$ ahUKEwi88svKycDlAhXOo4sKHU9a C48QFjAJegQIBxAC\&url=https $\% 3 \mathrm{~A} \% 2 \mathrm{~F} \% 2 \mathrm{Fsro}$ sovet.ru\%2Fcode $\% 2$ Fcore $\% 2$ Fdownload.php\%3F1 $804 \& u s g=A O v V a w 11$ UYOqs5Vv1ANoXiA0AjUD [in English].

Стаття надійшла до редакції журналу 30.07.2019 